\title{
Pembinaan Desain Produk Amplang Ikan sebagai Alternatif Usaha Rumahan bagi Ibu-Ibu PKK Desa Terantang, Barito Kuala
}

\author{
Training on Fish Amplang Product Design as A Home-Based Business Alternative for PKK \\ Members of Terantang Village, Barito Kuala
}

Rizky Nastiti*
Norbaiti
Masithah Akbar
Lydia Goenadhi
Department of Management, Sekolah
Tinggi Ilmu Ekonomi Indonesia
Banjarmasin, Banjarmasin, South
Kalimantan, Indonesia
email: rizky@stiei-kayutangi-
bjm.ac.id
Kata Kunci
Amplang ikan
Desain produk
Usaha rumahan
Keywords:
Fish amplang
Product design
Home business
Pubceived:
Pushed: October 2021

\begin{abstract}
Abstrak
Desa Terantang merupakan desa di Kabupaten Barito Kuala di mana ibuibu di sana tergabung sebagai anggota PKK yang menjadi tempat mereka belajar memulai usaha rumahan. Kebanyakan anggota PKK desa tersebut merupakan ibu rumah tangga yang baru memulai usaha seperti keripik bayam. Kegiatan ini bertujuan untuk memberikan alternatif usaha bagi mereka, dimulai dari menentukan dan mendesain produk yang sesuai dengan kondisi mereka hingga pelatihan pembuatan produk tersebut. Amplang ikan ditawarkan sebagai produk yang bisa dijadikan usaha alternatif mengingat bahan baku berupa ikan mudah didapatkan dan tidak memerlukan peralatan khusus dalam pembuatannya. Kegiatan ini dilaksanakan dengan metode pemberian materi mengenai desain produk dan mempraktekan pembuatan amplang ikan yang diajarkan oleh seorang pengusaha amplang. Dari kegiatan yang dilaksanakan tersebut, para peserta mendapatkan keterampilan baru mengenai desain produk amplang ikan. Selain itu pelatihan ini diharapkan menjadi bekal bagi mereka untuk mengembangkan usaha yang mereka miliki. Dari hasil evaluasi didapatkan bahwa peserta merasa puas dengan kegiatan yang dilaksanakan apalagi mereka dapat belajar keahlian baru. Mereka juga meminta agar pelatihan serupa dapat diadakan secara berkala.
\end{abstract}

\begin{abstract}
Terantang Village is located in Barito Kuala Regency, where the women are members of the PKK, which is where they learn to start a home business. Most PKK members are housewives who have just started small businesses such as spinach chips. This training aimed to provide the participants with a business alternative, from determining and designing products that suit their conditions to training on how to produce these products. Fish amplang was offered as an alternative product, considering that the raw material in the form of fish is easy to obtain and does not require special equipment in its manufacture. This activity is carried out by providing material about product design and practicing making fish amplang taught by an amplang business owner. From the activities carried out, the participants gained new skills regarding the design of fish amplang products. In addition, this training is expected to be a provision for them to develop their businesses. Furthermore, from the evaluation results, it is found that the participants are satisfied with the training carried out, especially since they can learn new skills. They also request that similar training be held periodically.
\end{abstract}

(C) 2021 Rizky Nastiti, Norbaiti, Masithah Akbar, Lydia Goenadhi. Published by Institute for Research and Community Services Universitas Muhammadiyah Palangkaraya. This is Open Access article under the CC-BYSA License (http://creativecommons.org/licenses/by-sa/4.0/).

DOI: https:// doi.org/10.33084/pengabdianmu.v6i6.2201

\section{PENDAHULUAN}

Memulai usaha rumahan bukanlah perkara yang sederhana, banyak hal yang harus diperhatikan, antara lain produk yang akan dijual, pasar yang ditargetkan, dan tentu saja modal yang dimiliki. Begitu pula bagi yang telah memiliki usaha sendiri dan ingin 
mengembangkan usahanya. Menentukan produk yang dijual merupakan hal yang perlu direncanakan dengan baik karena pemilihan produk yang tepat adalah kunci kesuksesan (Heizer \& Render, 2016; Supriyanto, 2009). Hal ini juga dirasakan oleh ibu-ibu Desa Terantang, Kecamatan Mandastana, Kabupaten Barito Kuala yang tergabung sebagai anggota PKK Desa Terantang. Meskipun selama menjadi anggota PKK mereka diajarkan dan dibina hingga mampu memulai usaha rumahan seperti keripik bayam dan keripik kelakai, mereka masih kesulitan untuk menjalankan usaha mereka terutama di saat mereka kesulitan mencari bahan baku pembuatan keripik. Selain itu, mereka juga ingin menghasilkan produk baru agar bisa terus berkembang. Berdasarkan survey dan wawancara yang dilakukan kepada ibu-ibu PKKDesa Terantang, dapat disimpulkan bahwa ibu-ibu PKK memerlukan alternatif usaha baru yang dapat mereka jalankan di rumah. Usaha yang mereka harapkan adalah usaha yang bahan bakunya mudah didapatkan dan pembuatannya tidak memerlukan peralatan yang rumit. Karenanya, produk amplang ikan dimunculkan sebagai solusi potensial untuk dijalankan (Srihadiastuti \& Hidayatullah, 2018).

Amplang ikan merupakan salah satu produk yang dapat dijadikan alternatif usaha terutama bagi daerah yang memiliki potensi perikanan (Sari \& Hafid, 2019). Salah satu keunggulan memproduksi amplang ikan adalah bahan bakunya yang tidak hanya menggunakan ikan tenggiri tetapi juga ikan-ikan lain yang lebih terjangkau harganya dan mudah didapatkan seperti ikan bandeng, ikan malalugis, ikan pipih, ikan patin, ikan lele dan ikan gabus (Yunus et al., 2017; Cahyono et al., 2018; Evi et al., 2012; Maisur et al., 2019; Purnomo \& Suhanda, 2014).

Berdasarkan penelitian yang dilakukan oleh Maisur et al. (2019), pemilihan bahan baku ikan air tawar dapat mempengaruhi karakteristik mutu amplang ikan. Hasil penelitian juga menyimpulkan bahwa pembuatan kerupuk amplang dengan penggunaan jenis ikan air tawar berbeda memberikan pengaruh yang nyata terhadap rupa, aroma, tekstur dan rasa dari amplang serta kadar protein dan kadar lemak (Sari et al., 2021).

Berdasarkan kondisi dan permasalah yang dihadapi ibuibu PKK Desa Terantang dalam mengembangkan usaha mereka, kegiatan pengabdian kepada masyarakat ini difokuskan untuk memberikan alternatif usaha bagi mereka, dimulai dari menentukan dan mendesain produk yang sesuai dengan kondisi mereka hingga pelatihan pembuatan produk tersebut. Amplang ikan ditawarkan sebagai produk yang bisa dijadikan usaha alternatif mengingat bahan baku berupa ikan mudah didapatkan dan berbagai jenis ikan baik ikan air laut maupun ikan air tawar dapat digunakan sebagai bahan baku. Selain itu, pengolahan amplang ikan tidak memerlukan peralatan khusus (Sari \& Hafid, 2019).

\section{METODOLOGI}

Kegiatan pengabdian kepada masyarakat di Desa Terantang ini dilakukan dengan pendekatan partisipatif. Hal ini dimaksudkan agar peserta terlibat langsung dalam kegiatan. Kegiatan ini dilakukan melalui beberapa tahap, antara lain:

1. Survey awal di mana diskusi dan wawancara dengan 20 orang ibu-ibu peserta PKK Desa Terantang dilakukan.

2. Pemberiaan materi mengenai pentingnya desain produk dalam upaya memulai usaha dan mengembangka usaha yang ada.

3. Pelaksanaan kegiatan praktek di mana Ibu Parti, seorang pengusaha produk rumahan salah satunya amplang, memberikan materi dan melibatkan peserta dalam pembuatan amplang.

4. Evaluasi kegiatan.

Untuk mengukur keberhasilan dari kegiatan pengabdian kepada masyarakat ini, pendekatan 
kualitatif diambil. Di akhir kegiatan para peserta diminta untuk mengisi kuesioner evaluasi kegiatan dalam rangka mengukur peningkatan pengetahuan peserta tentang materi yang diberikan serta menilai kegiatan yang telah dilaksanakan.

\section{HASIL DAN PEMBAHASAN}

Kegiatan pengabdian kepada masyarakat bagi ibu-ibu PKK Desa Terantang ini dilakukan melalui beberapa pertemuan. Kegiatan pelatihan diisi dengan pemberian materi, pemutaran video, diskusi dan tanya jawab serta mendatangkan pemateri luar, yaitu seorang pengusaha untuk memberikan bimbingan langsung dalam pembuatan produk.

Pada pertemuan pertama, pemateri mengunjungi Desa Terantang, Kecamatan Mandastana, Barito Kuala untuk menemui ibu-ibu anggota PKK di sana. Kegiatan banyak diisi dengan diskusi dan tanya jawab. Tujuan dari diskusi tersebut adalah untuk mencari tahu keinginan usaha dan kendala mereka dalam memulai usaha. Dengan diskusi ini, diharapkan pada pertemuan berikutnya pelatihan dan bimbingan yang sesuai dengan kebutuhan peserta dapat diberikan. Dari diskusi tersebut disimpulkan bahwa para peserta sangat antusias untuk memulai usaha baru. Mereka sebelumnya juga telah menggeluti beberapa usaha seperti produksi keripik bayam, keripik kelakai dan kerupuk.

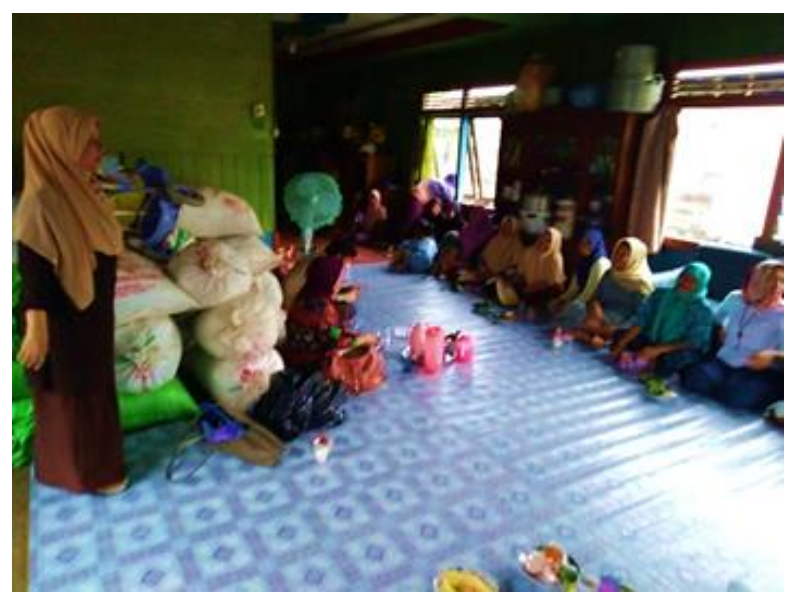

Gambar 1. Diskusi dengan Ibu-Ibu PKK
Pada pertemuan berikutnya, materi mengenai pentingnya desain produk dalam rangka memulai usaha kecil diberikan. Di awal kegiatan, video mengenai kiat-kiat memulai usaha ditampilkan. Setelah itu, usulan mengenai jenis usaha yang dapat peserta lakukan juga diberikan.

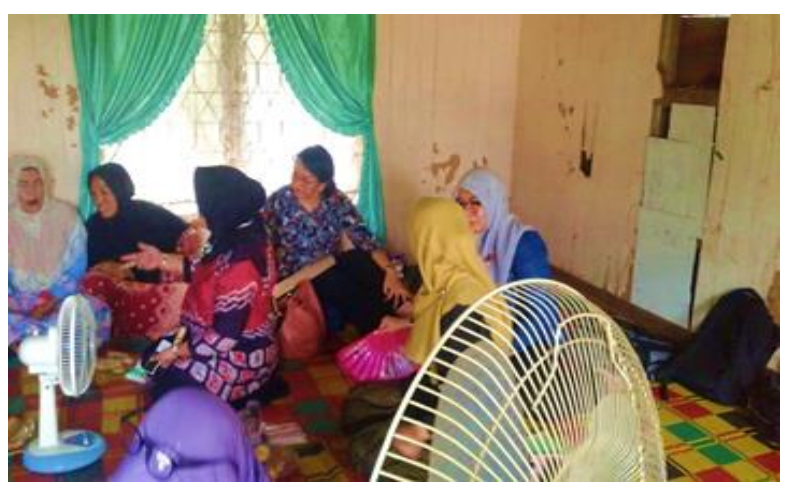

Gambar 2. Pemberian Materi

Beberapa usulan yang diajukan, antara lain: 1) Usaha makanan ringan, yaitu keripik sayur, keripik bongol, dan keripik jamur; dan 2) Usaha kerajinan tangan, yaitu kerajinan dari sampah plastik, dan kerajinan dari koran bekas. Setelah itu, video mengenai kisah sukses pengusaha Amplang Patin dari Tabalong ditampilkan. Selanjutnya, diadakan diskusi dan tanya jawab mengenai usulan usaha yang dianggap menarik dan mungkin dilakukan oleh peserta. Dari hasil diskusi, diputuskan bahwa ibu-ibu PKK akan belajar membuat amplang pada pertemuan berikutnya.

Pada pertemuan terakhir, Ibu Parti, seorang pengusaha amplang diundang sebagai narasumber. Beliau mengajarkan kepada peserta mengenai cara membuat produk, dimulai dari mempersiapkan bahan-bahan, mengolah adonan, dan menggoreng adonan hingga menjadi produk amplang yang siap konsumsi. Tahaptahap pembuatan amplang, yaitu:

1. Menyiapkan bahan-bahan membuat amplang

2. Membuat adonan amplang

3. Membentuk adonan amplang

4. Menggoreng amplang 


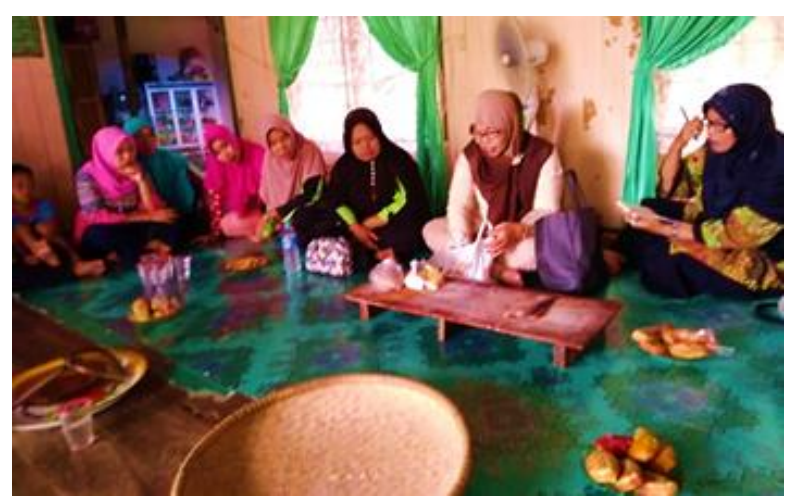

Gambar 3. Narasumber Mempraktekan Pembuatan Amplang

Setelah narasumber memberikan contoh proses pembuatan amplang, para peserta diminta untuk mempraktekan langsung pembuatan amplang. Narasumber juga memberikan tips dan trik agar produk amplang yang dihasilkan renyah dan tidak mudah melempem.

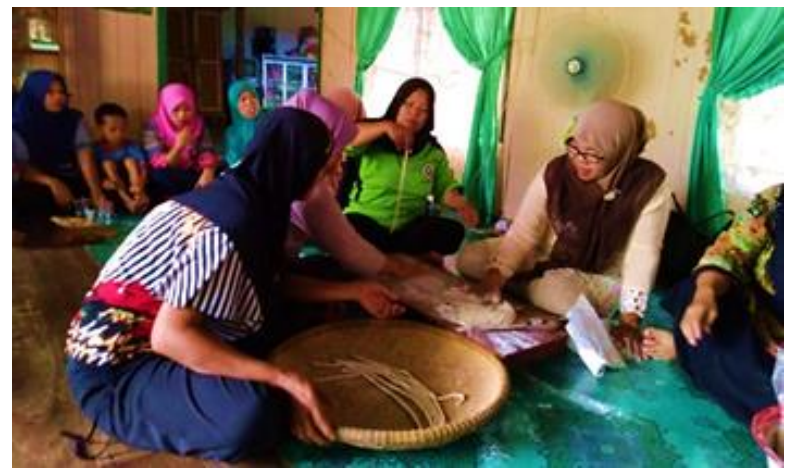

Gambar 4. Praktek Pembuatan Amplang

Setelah berhasil mempraktekan pembuatan amplang, diadakan tanya jawab sambil menikmati cemilan amplang yang dibuat peserta.

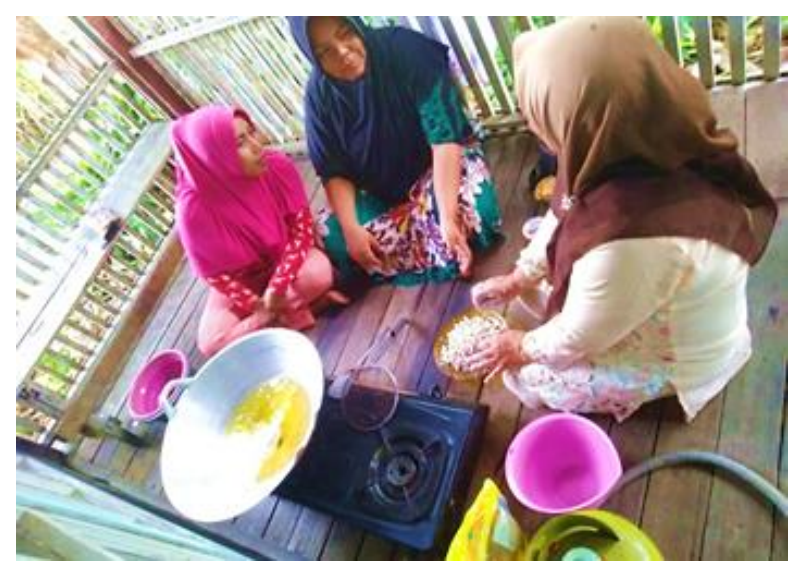

Gambar 5. Diskusi antara Peserta dan Narasumber
Diakhir kegiatan, peserta diminta untuk mengisi kuesioner evaluasi kegiatan dalam rangka mengukur peningkatan pengetahuan peserta tentang materi yang diberikan. Peserta juga diminta untuk menilai kegiatan yang telah dilaksanakan. Dari hasil evaluasi didapatkan bahwa peserta dapat menerima dengan baik materi yang diberikan. Selain itu, pada kuesioner evaluasi yang diberikan kepada peserta setelah mengikuti kegiatan pelatihan, terdapat tiga poin yang dievaluasi yaitu pembicara, materi, dan jalannya acara secara keseluruhan. Pada kuesioner, peserta diminta untuk memberikan penilaian dengan nilai 1 sampai 5. Hasil penilaian peserta terhadap kegiatan yang telah dilaksanakan dapat dilihat pada Gambar 6.

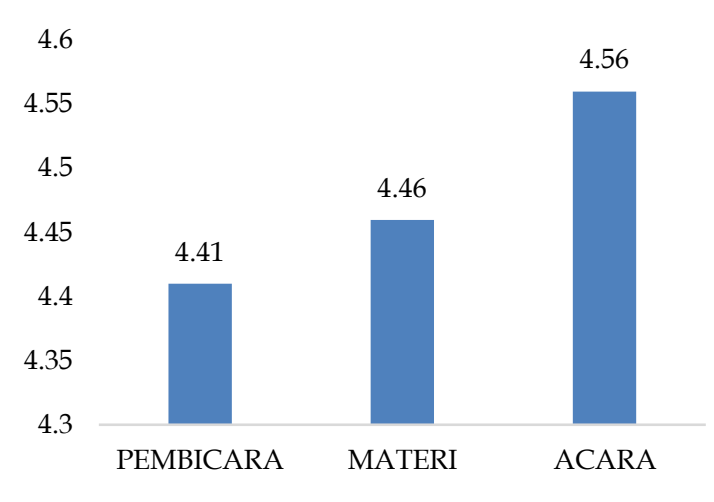

Gambar 6. Hasil Evaluasi Pelaksanaan Kegiatan

Dapat dilihat pada Gambar 6 bahwa penilaian terhadap pembicara, materi, dan jalannya acara secara keseluruhan diatas 4 yang artinya menurut penilaian peserta kegiatan telah berlangsung dengan baik. Dari hasil evaluasi juga didapatkan bahwa peserta merasa puas dengan kegiatan yang dilaksanakan apalagi mereka dapat belajar keahlian baru. Mereka juga meminta agar pelatihan serupa diadakan secara berkala.

\section{KESIMPULAN}

Produk amplang ikan merupakan salah satu alternatif usaha rumahan bagi pengusaha kecil yang ingin mengembangkan usahanya maupun bagi yang ingin 
memulai usaha. Salah satu keunggulan dari usaha amplang ikan adalah bahan bakunya yang dapat menggunakan berbagai jenis ikan. Sehingga jenis ikan yang lebih terjangkau harganya dan mudah didapatkan seperti ikan patin juga dapat digunakan sebagai bahan baku. Secara keseluruhan kegiatan ini dinilai bermanfaat bagi ibu-ibu PKK Desa Terantang. Dengan diadakannya kegiatan ini, peserta diharapkan mampu membuat produk amplang khas daerah mereka sendiri. Sesuai dengan hasil evaluasi, kegiatan berikutnya diharapkan dapat berfokus pada alternatif usaha rumahan lain seperti pembuatan kue kering dan kue khas banjar.

\section{UCAPAN TERIMA KASIH}

Tim pelaksana kegiatan mengucapkan terima kasih kepada STIE Indonesia Banjarmasin dan Ketua LPPM STIE Indonesia Banjarmasin atas dana dan dukungan yang diberikan sehingga kegiatan ini dapat berlangsung dengan lancar. Selain itu, apresiasi ditujukan kepada Kepala Desa Terantang beserta seluruh perangkat desa atas bantuannya. Tidak lupa kami sampaikan terima kasih kepada Ibu Parti, selaku narasumber.

\section{REFERENSI}

Cahyono, E., Mandeno, J.A., Rieuwpassa, F.J. 2018. Peningkatan Keterampilan Pengolah Amplang Ikan di Desa Kendahe Kepulauan Sangihe. Jurnal Ilmiah Tatengkorang. 2:77-81.

Evi, S.U., Mahreda, E.S., Dekayanti, T. 2012. Analisis Usaha Pengolahan Amplang Ikan Pipih (Notopterus chilata) Skala Rumah Tangga di Kota Palangka Raya Provinsi Kalimantan Tengah. Fish Scientiae: Jurnal Ilmu-Ilmu Perikanan dan Kelautan. 2(3):64-74. http://dx.doi.org/10.20527/fs.v2i3.1152

Heizer, J. Render, B. 2016. Manajemen Operasi: Manajemen Keberlangsungan dan Rantai Pasokan (11 th ed.). Jakarta: Salemba Empat.

Maisur, W.A., Desmelati, Dewita. 2019. Pengaruh Jenis Ikan Air Tawar Berbeda Terhadap
Karakteristik Mutu Kerupuk Amplang Ikan. Jurnal Agroindustri Halal. 5(2):151-160. https://doi.org/10.30997/jah.v5i2.1801

Purnomo, Suhanda, J. 2014. Diversifikasi Olahan Berbasis Ikan Patin Di Desa Jingah Habang Hilir Kecamatan Karang Intan Kabupaten Banjar KalimantanSelatan. Fish Scientiae: Jurnal Ilmu-Ilmu Perikanan dan Kelautan. 4(8):80-94. http://dx.doi.org/10.20527/fs.v4i8.1121

Sari, H., Hafid, A. 2019. Pengembangan Usaha Kerupuk Amplang Bandeng untuk Memberdayakan Masyarakat Desa Polejiwa Kecamatan Malangke Barat Kabupaten Luwu Utara Provinsi Sulawesi Selatan. Panrita Abdi: Jurnal Ilmiah Pengabdian Pada Masyarakat. 3(2):161169. https://doi.org/10.20956/pa.v3i2.5624

Sari, W.K., Sari, N.I., Leksono, T. 2021. Pengaruh Penambahan Tepung Rumput Laut (Eucheuma sp.) Terhadap Mutu dan Karakteristik Amplang Ikan Tongkol (Euthynnus affinis). Jurnal Teknologi dan Industri Pertanian Indonesia. 13(1):9-15. https://doi.org/10.17969/jtipi.v13i1.18349

Srihadiastuti, R., Hidayatullah, D.S. 2018. Analisis Penyebab Kegagalan Mendirikan Usaha Baru Pada Para Lulusan Program Wirausaha Baru Jawa Barat Kelas Ide Bisnis. Jurnal Ekonomi Pendidikan dan Kewirausahaan. 6(1):31-44. https://doi.org/10.26740/jepk.v6n1.p31-44

Supriyanto. 2009. Business Plan Sebagai Langkah Awal Memulai Usaha. Jurnal Ekonomi dan Pendidikan. 6(1):73-83.

https://doi.org/10.21831/jep.v6i1.590

Yunus, M., Maknunah, J., Sujito. 2017. Peningkatan Usaha Krupuk Amplang Di Desa Kertasada Kecamatan Kalianget Kabupaten Sumenep. Jurnal Dedikasi. 14:35-39. https://doi.org/10.22219/dedikasi.v14i0.429 7 